\title{
The French Referendum: The Not So Simple Act of Saying Nay
}

\section{Introduction}

For the second time in the history of the French Vth Republic, the first having led to the resignation of Charles De Gaulle in 1969, a president lost a national referendum ${ }^{1}$. On May 29, 2005, 54.7\% of French voters rejected the European Constitutional Treaty, even though France was one of the major proponents of the European Convention which led to the Constitution's drafting. The victory of the "no" vote had been foreseen, ${ }^{1}$ but neither the margin of victory, nor the high turnout (almost $70.5 \%$ ) were expected. The rejection of the Constitution raised two concerns: the first related to the position of France in Europe, the second to its domestic impact. Why did the French electorate vote as it did? Did voters make up their minds based on national cues, the European issue being generally of little importance even in European elections (Franklin, Marsh, and McLaren 1994; Van der Eijk and Franklin 1996)? Is the referendum result the consequence of a growing anti-European attitude, which could cause considerable damage to the process of EU integration? Will a new cleavage grounded on attitudes to Europe and capable of

by

\section{Sylvain Brouard,} CEVIPOF/Sciences Po Paris Vincent Tiberi, CEVIPOF/Sciences Po Paris altering the traditional left-right organization emerge in the French political system?

The 2004 European parliamentary elections were characterized by a relative decline for the anti-EU parties, which gained barely $25 \%$ of votes cast (see Cautrès and Tiberj 2005: Perrineau 2005). Furthermore, the anti-EU coalition in France remains somewhat heterogeneous, bringing together extremeleft parties, the Communists, a minority of the Socialist Party, several Gaullists and the extreme-right. Nevertheless, the failure of the referendum gave a new impulse to the anti-EU faction, which is now suggesting a re-composition of the traditional French political order along the lines of the European cleavage. The impact of the referendum result has fast become a burning issue both in academic circles and politically for the future of France and Europe. $^{2}$

\section{Competing Explanations for the Rejection of the ECT}

Several sometimes contradictory theories have been put forward to explain the result of the referendum. They can be broadly divided into four hypotheses.
First, was the result of May 29 in some way similar to that of April 21 2002, when the extreme-right candidate, Jean-Marie Le Pen, qualified for the second round of the presidential election instead of Socialist Prime Minister Lionel Jospin? Some politicians and journalists have stressed the features common to both these electoral events, in particular, arguing that by voting against the positions advocated by the ruling parties (the Socialist Party, UDF, UMP) French voters have once again voiced their dissatisfaction with the political elites, their lack of responsiveness, and their inability to solve the major problems facing the nation. According to this hypothesis, therefore, the rejection of the ECT is a vote of distrust connected to national issues directly rather than to the European issue itself. So the first hypothesis - "the political distrust hypothesis"- -states that the rejection of the ECT is first a rejection by the people of their political elites.

Second, was the May 29 result a vote against Europe? Thirteen years after the French adoption of the Maastricht Treaty by a narrow margin $(51 \%)$, positions on Europe among the electorate have not changed. According to a certain viewpoint, France is still divided along a major value cleavage which directly affects the level of anti-European attitudes and which does not correspond to the traditional left-right divide. Some French scholars describe it as the open/closed cleavage (Chiche, Le Roux, Perrineau, and Rouanet 2000). On the one hand, an open-minded constituency supports multiculturalism, tolerance toward immigrant populations and others minorities, and European integration. These attitudes flourish among the highly educated, younger generations, and the upper class. On the other hand, the lower classes and less educated represent a more culturally conservative electorate, which is characterized by a rejection of European integration, homophobia, and ethnocentrism. ${ }^{3}$ According to this hypothesis, the "yes" vote would be "open" and the "no" vote "closed" the "yes" vote pro-European and the "no" vote anti-European. It posits that the French electorate has become more closed in the last decade. Consequently, the "no" vote has increased to the extent that it now prevails in France. The second hypothesis - "the antiEurope hypothesis"-explains the rejection of the ECT as a rejection of the process of European integration itself.

The third hypothesis suggests that the May 29 vote was a rejection of a particular Europe. It would be misleading to consider the "no" vote an expression of global anti-European attitudes only. Already in the 2004 European 
elections, the Socialist Party focused its campaign on the struggle for a Europe sociale, against globalization and economic liberalism. These were the issues voiced by the left opponents to the ECT one year later. In fact, during the 2004 elections, the lower classes returned to the pro-integration position of the Socialist Party, expressing their demands for social protection and their concerns about rising inequalities in France (see Cautrès and Tiberj 2005). Through the referendum, voters may not have been expressing a rejection of Europe as a whole, but condemning a particular Europe, a Bolkenstein's Europe (named after the former EU-commissioner who proposed an increased liberalization of services). This could explain why the "yes" vote lost ground among public servants, irrespective of their level of education, many of whom expressed the fear that Europe is a direct threat toward the French public sector and welfare system. The image of an economically liberal Europe was also mobilized to convince the more vulnerable in society, blue-collar and office workers for example, about the process of economic globalization. Given the growing Europeanization of policies, a policy oriented EU-skepticism exists alongside a rejection of European integration itself. Voting against an EU-policy does not automatically imply an anti-European stance, but could be a criticism of a specific policy orientation. So, the third hypothesis- "the EUcriticism hypothesis" - explains the rejection of the ECT as a policy-disagreement and not an anti-European attitude.

According to the fourth hypothesis, the May 29 result can be seen as a vote against President Jacques Chirac. Referenda in France are unfortunately often associated with the plebiscite tradition created by Napoleon the Third and enhanced by De Gaulle (see Morel 1996; 2005). This instrument of direct democracy has often been used by a president to strengthen his own power. The lack of popularity of the President Chirac and his government might therefore be taken into account, particularly after the major electoral defeats of 2004 (for the first time since 1988, the left won a majority of votes cast during regional elections). Furthermore, the link between the result of a referendum and the level of popularity of the politicians in office becomes even stronger with the complexity of the issues, and European integration is a very complex issue (Franklin, van der Eijk, and Marsh 1995). Under this assumption, Europe becomes the collateral damage of national politics, which says a lot about the importance of European integration for French voters. This last hypothesis- "the executive popularity hypothesis"-explains the rejection of the ECT as an indicator of the president's and government's popularity.

This paper evaluates the relevance of these four hypotheses for the electorate as a whole and for particular segments of the French public arguing that the rejection of the European Constitution by French voters was motivated by different factors.

More importantly, the failure of the referendum raises concerns about the future of French politics and the process of European integration. Finally, we use data from two pre-election surveys to evaluate whether a new political space is rising out of the ashes of the May $29^{\text {th }}$ vote. $^{4}$

\section{Where Do the Nays Come from? A First Overview}

A study of the socio-political profile of the "no" vote is a necessary step before attempting to analyze the relevance of the different hypotheses.

The "no" vote made progress in virtually all social groups (see Table 1) when comparing the results of the previous two referenda on Europe. If one looks to occupation as an explanatory factor, voting distributions in 1992 and in 2005 follow the same trend: the higher the class level of the individual's profes-
Table 1

The Sociopolitical Support for the "No" in
the Last Two European Referenda

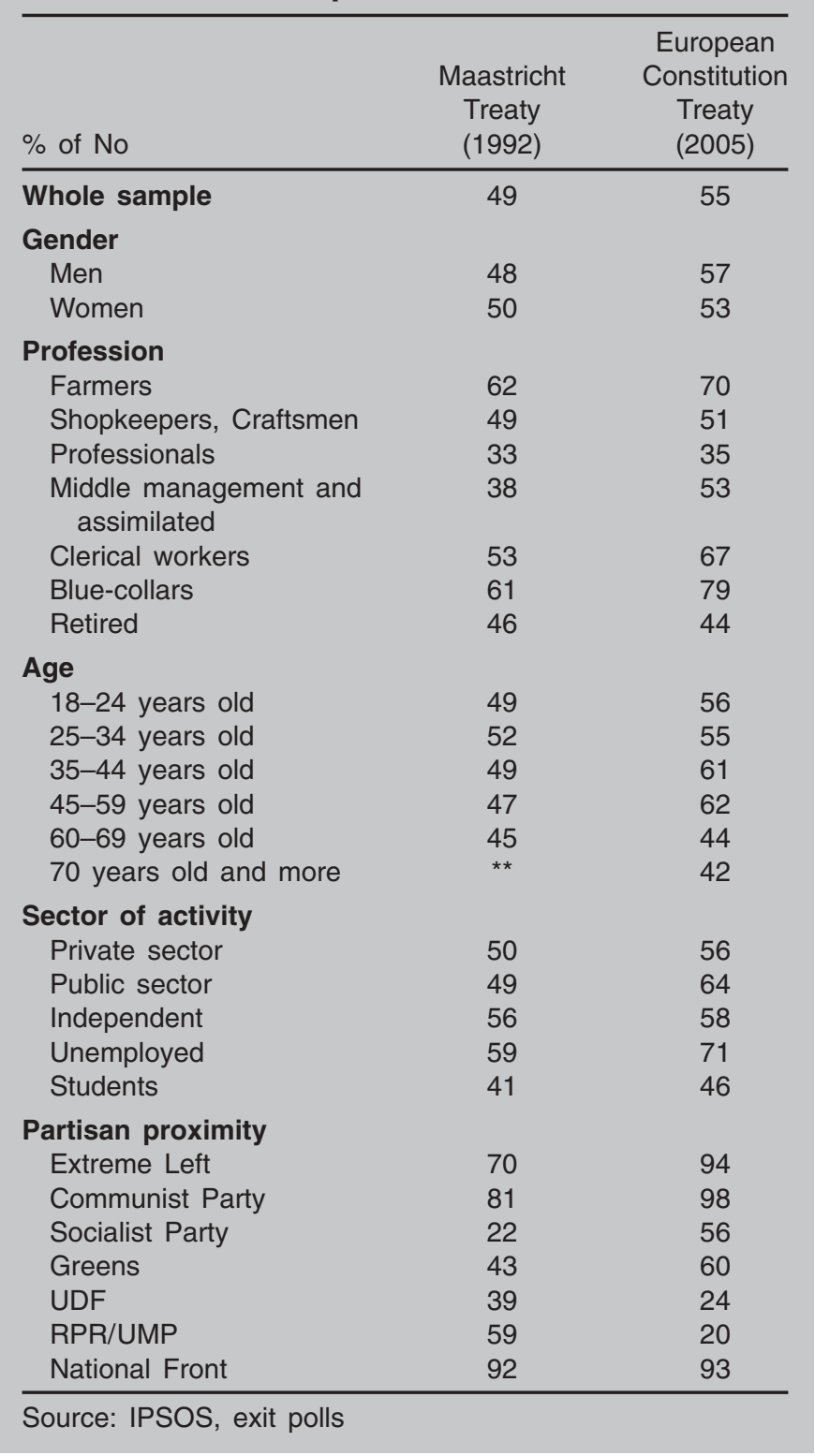

sion, the higher the probability that they will support the European Treaties (35\% of nays among professionals, $79 \%$ among blue-collar workers in 2005). Two facts must be pointed out. First, the progress of the "no" vote differs in the various occupational groups ranging from -2 among the retired and +2 among shopkeepers, craftsmen, and professionals, to +14 and more among the middle and lower classes. In 2005, the different social groups were more polarized on the subject of Europe than in 1992. Second, the social basis of the "yes" vote diminished during this same period: majority support for the ECT was visible only among professionals and the retired in 2005, whereas in 1992 middle management, shopkeepers, and craftsworkers also supported it. The increase of the "no" vote was not limited to the private sector, though this is the sector most endangered by globalization and lay-off plans, one of the most hotly debated issues among the public and in the media during the campaign (see Piar and Gerstlé 2005). Public servants were more likely to vote against the ECT than their private sector counterparts, thus showing their concern about EU policies on public 
services and public companies (such as railroads, phone, and electricity operators, all of which are under state control). They therefore fall into the category of the EU-criticism hypothesis.

Age also plays a role. In 1992, age groups split more or less in similar proportions between the "yes" and the "no" camps. In 2005 , the "no" vote gained ground amongst all age groups except for individuals aged 60 or more. The "no" vote reached its highest point among individuals in the middle of their professional careers (aged 35 to 59). It is also among this age group that negative perceptions of the state of the economy are the most widespread and that the vote for the moderate right has decreased the most in the 2004 regional and European elections. The economic and political features sustaining the political distrust, the EU-criticism, and the executive popularity hypotheses are found in individuals in this age group.

But even if social variables such as occupation, sector of activity, or age provide clues to understanding the referendum result, one cannot neglect the importance of politics. Voting distribution by partisan proximity shows both permanent features and dynamics: at the extremes of the French political space, large numbers of both extreme-right- and extreme-leftwing party supporters voted "no" in 1992 and in 2002. UDF voters continue to demonstrate their attachment to European integration and constitute the only political group to support both the European treaties. For the remaining three political groups the changes are dramatic: Socialists and Greens said "yes" in 1992 and "no" in 2005, the Gaullists (RPR and UMP) changed direction completely, going from rejecting the Maastricht Treaty to supporting the ECT.

Hence, all four hypotheses set forth above are potentially valid. For example levels of ethnocentrism (Mayer 1999) and of Euro-skepticism (Belot and Cautrès 2004) reach their highest point among the lower classes, but so too do feelings of economic threat related to European policies (Cautrès and Tiberj 2005) and dissatisfaction with the political process and the government (Schweisguth 2002; Bréchon, 2004). It is important to determine which of these factors precisely incited blue-collar and office workers to vote "no". Which of our four hypotheses correspond to them? Did the professionals vote "yes" because they are further to the right than other social groups and therefore more supportive of President Chirac's policies (the executive popularity hypothesis) or because they feel less threatened by economic globalization and therefore more open to Europe (the anti-Europe hypothesis)? The executive popularity hypothesis seems relevant since the only voters to support the ECT were those aligned with the moderate right-wing currently in office, just as the left-wing voters aligned with President François Mitterrand in 1992. We must therefore use a multivariate analysis to offer a coherent explanation for the various causes of the negative vote.

\section{Results}

A lot has been said about the role of political parties in the referendum result. Divisions within the Socialist Party, for example, were said to be a reason behind the high number of "no" votes among left-wing voters. With an internal poll in December 2004 showing 59\% of the militants opting for the "yes" vote but a minority of leaders campaigning actively for the "no" vote, the vote on May $29^{\text {th }}$ is considered a major defeat for the Socialist Party's Secretary-General François Hollande. It is also assumed that this defeat will have a negative impact on the performance of the Socialist candidate in the next presidential election. What the model demonstrates is, ceteris paribus, that Socialist leaning did not provide a significant push in favor of the "no" vote. Socialist leaners were as likely to vote "yes" as UMP or UDF voters, when their level of political and govern-

\section{Specifications of the model}

The independent variables are the following:

1. As control variables we chose partisan proximity ${ }^{5}$ and occupation.

2. For the "political distrust hypothesis," we chose the variable: "In France, how does democracy work? Very well, reasonably well, not well, not well at all," which was asked in the first wave of the survey. Thus we developed two models, the first including all the independent variables but only 646 individuals, and the second merging the two waves but without the political trust item.

3. For the "executive popularity hypothesis," we chose the level of satisfaction with the Raffarin government. $^{6}$

4. To evaluate if the "no" vote works along the "antiEurope hypothesis" or the "EU criticism hypothesis," the model asks two different sets of questions. The anti-Europe hypothesis is tested by using perceived threats which European integration could cause, in terms of French sovereignty: a belief that, because of Europe, France pays for other countries, that the number of immigrants is increasing, that France would lose its national identity and its culture, and that France plays a lesser role in the world. The EUcriticism hypothesis is evaluated through a second set of perceived threats which European integration could bring about in terms of the job market and social matters: a belief that, because of Europe, unemployment is rising and that social protection is decreasing.

In order to control for item-response ordering, for the specificities of each group included in the analysis, and to allow every possible form of relationship between independent and dependent variables, we chose to consider each modality of response as dummy variables. In Tables 2 and 3, we used a unique modality of reference for each independent variable (for example the UMP for partisan proximity or "retired" for the occupation variable). While consuming more degrees of freedom, this approach is particularly valuable, as we will show later.

mental dissatisfaction or their perception of Europe as a national or a social threat are taken into account.

A rather different picture emerges from the other left-wing parties. Among the Trotskyist and Communist voters, the "no" vote appeared certain. Even among the Greens, the "no" vote was always by far the most probable choice. But for the extreme left and Communist leaners, the explanation for their electoral behavior lies in the consensus of their political and social leaders. All the extreme-left organizations-whether partisan, trade-unionist, or associative (like, for example, ATTAC) openly rejected the ECT and for the first time effectively used the Internet to mobilize voters. Their proven consistency on the topic_-strongly advocating for a rejection of the Maastricht treaty-was also crucial, though in 2005 they did not express their opposition to Europe as a whole, but rather they argued in favor of Europe "but not this one." Their goal is a Europe capable of developing strong protection against globalization and the promotion of a continental version of the French social model.

Like the Socialists, the Green party's internal consultation revealed proponents of and opponents to the ECT. In this case, the significant tendency toward the "no" vote reveals the weak relationship between this organization and its constituency. ${ }^{7}$ 
Table 2

\section{Logistic Regression Predicting the "No" Vote in the Referendum: Model with the Political Trust Hypothesis}

\begin{tabular}{|c|c|c|c|c|}
\hline & B & E.S. & Signif. & $\operatorname{Exp}(B)$ \\
\hline \multicolumn{5}{|l|}{ Partisan proximity } \\
\hline Extreme Left/Communist Party & 2.483 & .660 & .000 & 11.977 \\
\hline Socialist Party & -.005 & .337 & .987 & .995 \\
\hline Greens & 1.085 & .430 & .012 & 2.960 \\
\hline UDF & -.151 & .426 & .722 & .860 \\
\hline National Front & .576 & .672 & .391 & 1.780 \\
\hline $\begin{array}{l}\text { No party proximity } \\
\text { UMP }\end{array}$ & .884 & .468 & .059 & 2.421 \\
\hline \multicolumn{5}{|l|}{$\begin{array}{l}\text { Number of perceived European threats } \\
\text { on sovereignty }\end{array}$} \\
\hline 0 & -1.749 & .427 & .000 & .174 \\
\hline 1 & -1.438 & .421 & .001 & .237 \\
\hline 2 & -.653 & .386 & .091 & .521 \\
\hline 3 & .076 & .398 & .848 & 1.079 \\
\hline 4 & & & & \\
\hline \multicolumn{5}{|l|}{$\begin{array}{l}\text { Number of perceived European threats } \\
\text { on social matters }\end{array}$} \\
\hline 0 & -3.021 & .590 & .000 & .049 \\
\hline 1 & -1.088 & .271 & .000 & .337 \\
\hline 2 & & & & \\
\hline \multicolumn{5}{|l|}{ Occupation } \\
\hline Farmers, Shopkeepers, Craftsmen & .637 & .547 & .244 & 1.891 \\
\hline Professionals & .817 & .428 & .056 & 2.263 \\
\hline Middle management and assimilated & .565 & .323 & .080 & 1.759 \\
\hline Clerks & .978 & .337 & .004 & 2.660 \\
\hline Blue-collar workers & .309 & .380 & .416 & 1.362 \\
\hline Others & & & & \\
\hline \multicolumn{5}{|l|}{ Satisfaction with the Raffarin government } \\
\hline Very satisfied & -1.975 & .636 & .002 & .139 \\
\hline Slightly satisfied & -2.044 & .369 & .000 & .129 \\
\hline Slightly dissatisfied & -1.204 & .289 & .000 & .300 \\
\hline Very dissatisfied & & & & \\
\hline \multicolumn{5}{|l|}{$\begin{array}{l}\text { Judgment on how democracy functions } \\
\text { in France }\end{array}$} \\
\hline Very well & -1.509 & .567 & .008 & .221 \\
\hline Well & -.485 & .400 & .226 & .616 \\
\hline Poorly & -.179 & .413 & .665 & .836 \\
\hline Very poorly & & & & \\
\hline Constant & 2.141 & .589 & .000 & 8.507 \\
\hline Pseudo R2 & $58 \%$ & & & \\
\hline -2log-likelihood & 526.380 & & & \\
\hline Percentages of correct prediction & $80 \%$ & & & \\
\hline $\mathrm{N}$ & 648 & & & \\
\hline
\end{tabular}

Source: Referendum and European issues survey, 2005 described the phenomenon as a protest of working class France against the country's economically liberal elites. Taking all the other independent variables into account, this idea is not so clear. In fact, a gap exists between retired and active citizens, while differences in behavior between the lower classes (blue-collar or office workers) and the upper classes are insignificant. This is not to say that professionals and blue-collar workers have the same perception of Europe as a threat (in fact, $75 \%$ of working class citizens as compared to $44 \%$ of professionals see Europe as a threat both to the social welfare and health system and the level of unemployment), but class, the social networks, and their accompanying values were not a supplementary factor.

The political distrust hypothesis might have been pertinent, particularly after what happened on April 21, 2002. It might also have provided a clue for a better understanding of the social distribution of the "no" vote, since the greatest opposition to the ECT was by the unemployed and other economically disadvantaged groups. However, this has not proved to be the case. Whether one takes political distrust into account in the model only adds or subtracts one percentage point to the explained variance. For example, among lower class voters, whatever their judgment on the way democracy works in France, the "no" vote was the more probable choice. Among upper class individuals, the average probability of a "no" vote varies by as much as $-/+7 \%$. Last but not least, $45.5 \%$ of those who voted "no" believe that democracy works well in France. If political distrust was predictive of a particular type of behavior during the referendum, this would have been relevant for the level of turnout but not for a particular vote.

The executive popularity hypothesis is a more acute explanation, though only for some parts of the electorate. The government's unpopularity reached a historical high during this period. Only $22 \%$ of interviewees had confidence in Prime Minister Jean-Pierre Raffarin in May 2005 (TNSSofrès). Simultaneously, the level of confidence in Chirac barely reached $37 \%$. This is not a contextual effect of the referendum since confidence in Raffarin fell below

Most of its supposed sympathizers made their partisan choice as a refuge (believing that by so doing they were not choosing between the left and the right). In fact, the Green voters are the least ideologically positioned among left-wing party sympathizers $(58 \%$ are neither left nor right, in comparison with $29 \%$ of those with socialist leanings and $22 \%$ of those with an extreme left leaning). In this, members of the Green party show a similar disinterest in politics as such with Independents. The likelihood that they would vote "no" was therefore not connected to any specific party stance but to other factors, as will be demonstrated later.

The "return of class voting" theory was also highly publicized, both by left- and right-wing opponents to the treaty, who
40\% in October 2003 and has stayed under this level since then. Lack of popularity was also one of the main reasons for the electoral failures of the right in 2004, particularly since large numbers of right-wing voters did not mobilize to support their favored party during the regional and European elections (Cautrès and Tiberj 2005).

Taken alone as a predictor, the percentage of explained variance reaches $30 \%$ and taken with the other variables, is still significant. For respondents satisfied with the government $(33 \%$ of the sample), the average probability of a "no" vote is estimated at nearly $22 \%$. Among those dissatisfied with the government, the "no" vote reaches an average probability of $65 \%$. Even among the rare left-wing voters with a positive attitude 


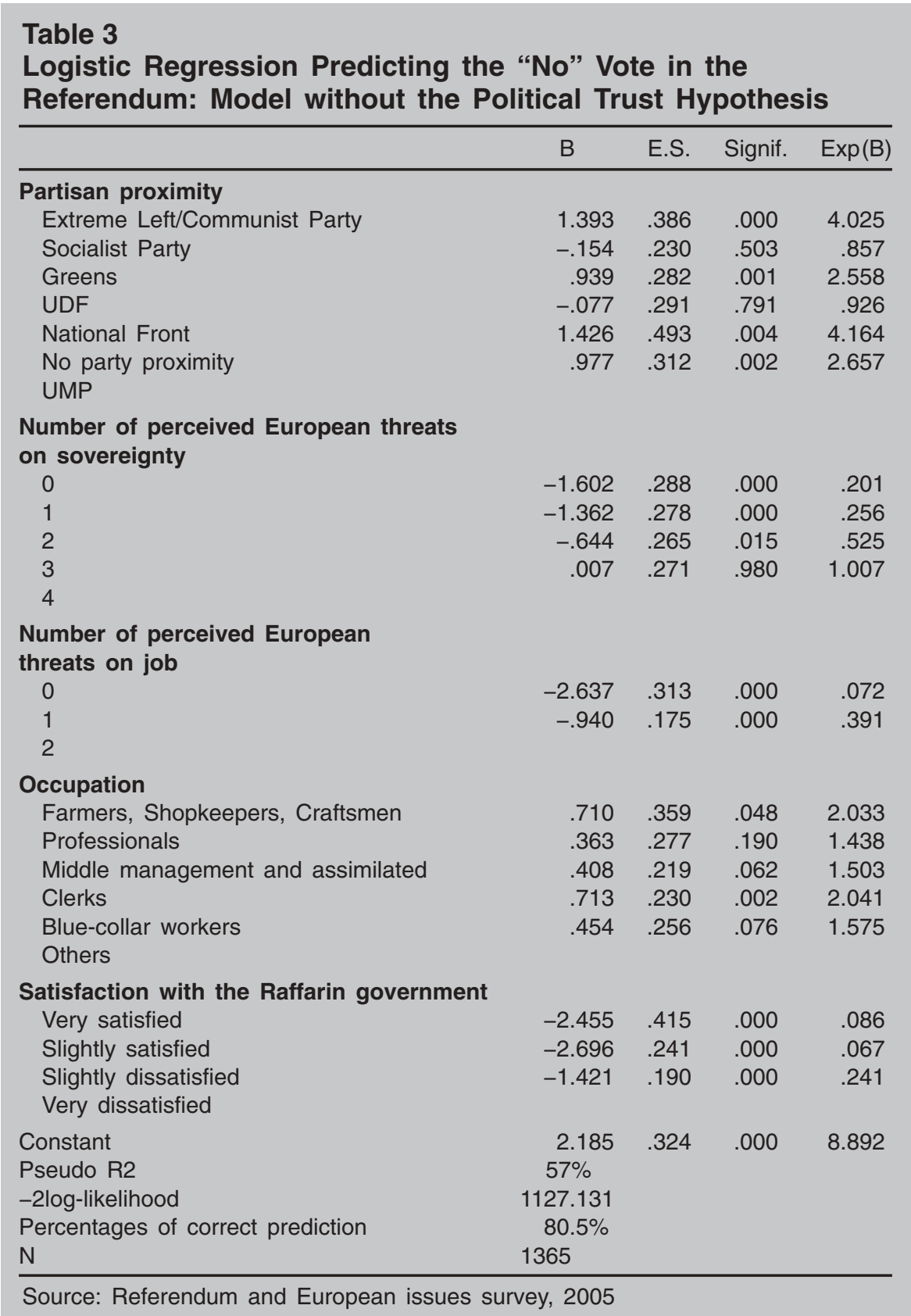

dum, Europe has been framed together with multiculturalism and immigration as a threat for France and its cultural identity. It is not a coincidence that this anti-European attitude is more common among the lower classes and the less well-educated: these sections of the population are also more prejudiced against immigrants and more culturally conservative, and therefore constitute the most closed-minded segment of the French public. Since 1992, several political entrepreneurs (such as Jean-Pierre Chevènement on the left or Philippe de Villiers and Charles Pasqua on the right) have tried to capitalize on the anti-European trend. However, apart from the European elections of 1994 and 1999, these attempts have not been successful. Politicians have rarely been able to convert anti-European attitudes into electoral success, but this does not mean that this issue disappeared after the Maastricht treaty referendum, as shown in Table 4. Comparing the public's perception of Europe as a threat between 2002 and 2005 clearly indicates that this perception is latent among the French electorate. The novelty of 2005 was the distinction between traditional perceptions of threats fuelled by nationalistic concerns and perceived threats to the social fabric. Europe is linked to questions of national identity, inter-member state solidarity, and sovereignty, particularly after EU-enlargement in 2004 to mostly East-European countries ${ }^{9}$-i.e. threats to national sovereignty - and simultaneous threats to the French socio-economic system, which resonate strongly within the context of the social and economic insecurity France has experienced since 2003. The perceived threat questions therefore offer a relevant empirical test for the anti-European hypothesis (threats to national sovereignty) and for the EU criticism hypothesis (threats to the socio-economic system).

A closer look at the perception of Europe as a whole is useful to underline the difference between anti-European attitudes and EU criticism. The survey asked four ques-

toward the government, only $8 \%$ are more likely to support the ECT. However, dissatisfied left-wing voters are present in both the "yes" and "no" electorates. In the former, $85 \%$ of the leftists criticized the policies implemented by Raffarin and his team, in the latter $96 \%$ did. Among socialist sympathizers, $56 \%$ is the average probability for the "no" vote among those dissatisfied by the government, in comparison with $90 \%$ among the extreme left and communist sympathizers. An explanation other than the executive popularity hypothesis must therefore be found to explain why the left split on the ECT.

Results are clearer for right-wing and "neither left nor right" voters. Among the right-wing, $62 \%$ of "no" voters criticized the government, while $82 \%$ of "yes" voters responded favorably to it. Among the neither left nor right voters, $85 \%$ of the "no" voters judged the executive negatively, while $55 \%$ of "yes" voters viewed it positively. ${ }^{8}$ Attitudes toward the government per se played a role in the results, but only among non-left voters.

The anti-European hypothesis is the first to explain the outcome of the referendum. Since the Maastricht Treaty referentions to measure the perceived threat to national sovereignty caused by Europe. Among the respondents who answered threatened four times, $42 \%$ said that European membership was positive for the country, $33 \%$ would regret and $32 \%$ would be relieved to see the European project withdrawn. Among those who felt more socially threatened by the EU, $56 \%$ believed membership in the EU was positive for France, $47 \%$ would regret and only $23 \%$ would be relieved should the European Project be withdrawn. It is clear that threats of a national and social order stem from two very different attitudes.

In any case, the model confirms this distinction. Both indicators are simultaneously significant and tell different stories when analyzed by the ideological position of individuals. Several scholars have argued that, regardless of party preference, there is one explanation for the "no" vote: a nationalistic rejection of Europe. The model presents a more complicated picture when the anti-European hypothesis is taken into account. True, the more Europe is perceived as a threat to national sovereignty, the greater the chance of a "no" vote, regardless of political 


\section{Table 4 \\ European Perceived Threats}

\begin{tabular}{lcc}
\hline & 2002 & 2005 \\
\hline $\begin{array}{l}\text { National Threats } \\
\ldots \text { that France pays for other countries (\% threatened) }\end{array}$ & 53 & 56 \\
$\ldots$ that we lose our national identity (\% threatened) & 54 & 48 \\
$\ldots$ that France has a less important role in the world & 34 & 32 \\
$\quad$ (\% threatened) & 55 & 49 \\
... that immigrant number will increase (\% threatened) & & \\
Social Threats & 69 & 68 \\
$\ldots$ that there is less welfare (\% threatened) & $* *$ & 78 \\
\hline ... that unemployment will rise (\% threatened)
\end{tabular}

among the pro-European electorate. An average probability of $73 \%$ and $74 \%$ (Table 6) of nays among the most socially threatened in these groups provides the last clue: among right-wing voters, social threats had a minor influence. This is not the case for the rest of the electorate: its average probability ranges from a virtually impossible nay to the overwhelming likelihood of such a choice. This also demonstrates that the "no" was a vote against a particular Europe, an economically liberal Europe, which we call EU-criticism, but which is not against the principle of the EU itself. For the left, where no nationalistic threat is perceived, $35 \%$ of voters still worry about levels of unemployment or social security and $42 \%$ worry about both of these issues. For neither left nor right voters, the percentages on these issues are respectively $29 \%$ and $22 \%$. alignment. This is particularly true among the neither left nor right faction and among the leftists who feel threatened by Europe. Those who feel more threatened by integration into the European Union are virtually certain to vote "no" (Figure 1). But a comparison between these two threatened groups and their equivalents on the right-wing provides another clue: among those less concerned by a perceived threat to the nation (the $54 \%$ who perceive no or only one threats), the probability of voting "no" is roughly four times greater than for the right-wing voters. Among the neither left nor right unthreatened by Europe ( $36 \%$ of this group) the probability of a "no" vote doubles or even triples in comparison with their rightist counterparts. This is to say that among the pro-European left, another type of logic, one which is neither distrust nor anti-governmental feelings, leads to a "no" vote.

Before going any further, another point must be made on reasons for the left-wing "no" vote. The right could have joined forces with the nays, but loyalty to the government strongly undermined the influence of the anti-European attitude on the right-wing "no" vote: for the more anti-European right-wing, which accounts for $33 \%$ of the right-wing electorate (Table 5), the average probability of a "no" vote remained low in comparison with the rest of the anti-European electorate. Chances are high that with a Socialist president their choice would have been different.

One explanation remains: the EU criticism hypothesis (i.e., threats to the social system). In fact, this hypothesis provides the needed complement to the anti-European hypothesis. Among the leftists, and to a lesser extent among the neither left nor right, it was difficult to explain such a high level of "no" votes

\section{Conclusion}

The French rejection of the European Constitutional Treaty stemmed from a sort of worst case scenario. Several reasons along the left-right axis led to this majority of nays, among which concerns about the social protection system played a particular role. Similarities between the 1992 and 2005 referenda exist. The perceived national threat existed 13 years ago, as did dissatisfaction with the government (Socialists at that time) and politics in general. The desire to vote against President Mitterrand explained quite well why the "no" vote was so important among his opponents. However, in 2005, the governmental frame was mobilized mostly among the right-wing and the neither left nor right factions, but not among the leftist voters; otherwise the European Constitution would have suffered a considerably higher nay. The novelty is clearly the perceived threat to the social fabric produced by European integration, which has also involved citizens who previously approved of this process and who do not fear for the future of the nation among a multicultural community.

We have rejected only one hypothesis: the political distrust hypothesis. The anti-European, EU-criticism, and executive popularity hypotheses are therefore relevant. Nevertheless their impacts vary among the French public. Anti-European attitudes come into play in virtually every political segment of the electorate (though their influence is greater among non-right-wing voters). EU-criticism brought voters who might otherwise have approved the ECT to the nay side. This is particularly the case for left-wing voters. The influence of the executive popularity question varies from a minor impact on the left to a strong impact for the rest of the electorate. If President Chirac had not

\section{Table 5}

\section{The French and Their Level of European Threats in 2005}

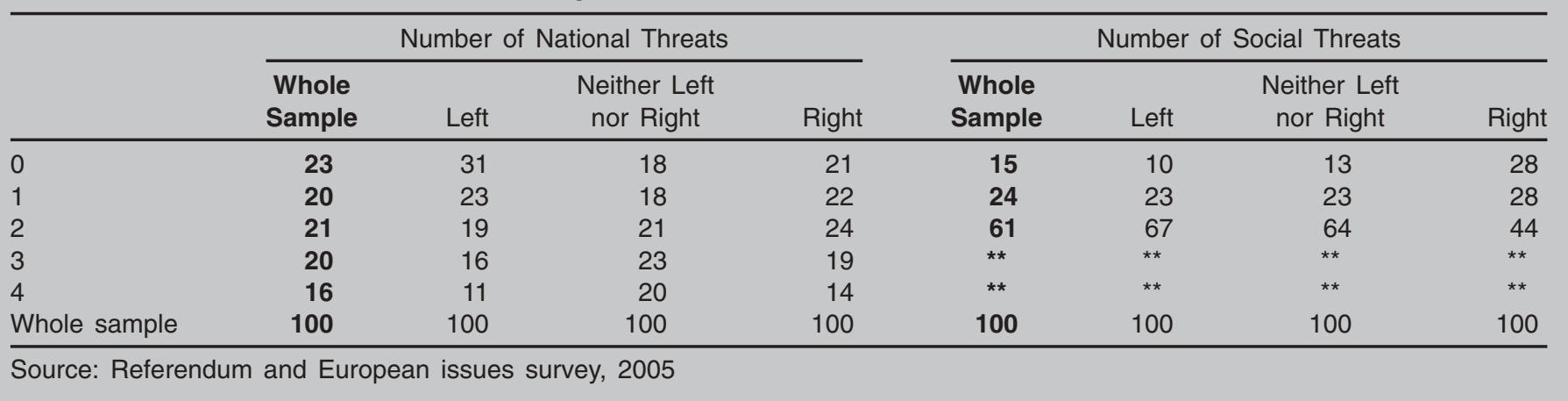




\section{Table 6 \\ The "No" Vote as a Response to Threats to Social Europe ("No" average probability)}

Number of

Perceived

Social Threats

0

1

2

Source: Referendum and European issues survey, 2005

been in office, several nationally-threatened right-wing voters would have voted nay.

Nevertheless, these heterogeneous electoral types of logic produced France's second political earthquake in the last three years (Sauger, Brouard, and Grossman 2006). On the left, preoccupation with social issues played the biggest factor for a negative vote, followed by, and to a lesser extent, the perceived nationalistic threat, and finally, and marginally, dissatisfaction with government. For neither left nor right voters, social and nationalistic preferences came together, reinforced each other, and was the main reason for their "no" vote, followed by dissatisfaction with the government. On the political right, the social threat was marginal in its influence; this was not the case with the nationalistic threat.

What consequences must be drawn, for Europe but also for French politics? Will the alliance forged in the referendum campaign, particularly among ECT opponents, reshape an already fragile French political equilibrium? The nays, particularly on the left, are attempting to capitalize on the rejection of the ECT by demanding new electoral alliances. Within the Socialist Party, factions are fighting for the leadership (and the presiden- tial candidacy) by competing both on the interpretations and the consequences of the vote. But, so far, the May $29^{\text {th }}$ vote has only had consequences for the political elite. The French public has gone back to its usual concerns, since the European issue is no longer on the agenda. Nays and yeas on the left are still potentially capable of rallying behind the same flag: the socialist flag. ${ }^{10}$ Neither left nor right voters would also vote for the Socialist Party. For the moment, political investment on the yes/no cleavage seems quite a risky choice to make, left/right issues are still more profitable.

Will France step back from the process of European integration? The French electorate remains divided on the topic but several indicators leave us with a nuanced picture. On the one hand, $65 \%$ of our respondents still judge retrospectively that French membership in the EU benefits the country. Fifty-eight percent would regret if the European project were abandoned. Sixty-six percent feel strongly or slightly committed to European integration. Among citizens with a positive attitude toward Europe, "no" voters are not marginal. ${ }^{11}$ This underlines the fact that this referendum was about a particular treaty, rather than about the place of France in Europe (although some ECT proponents tried to frame the referendum in this way). On the other hand, as far as the future is concerned, only $37 \%$ of interviewees ask for more power for European institutions to allow them to deal with future; 58\% prefer to rely on national institutions. French voters do not reject Europe but ultimately would not want its prerogatives on policy to be reinforced, at least under the conditions proposed in the ECT. But, what if Europe finds another way? What if Europe became the social safety net both opponents and proponents asked for during the campaign? The result of the referendum might have been dramatically different if perceived social threats had been lessened and if Europe had not been perceived as "liberal" but as "social." The question must be asked whether such a social policy change could be implemented and whether, indeed, such an option would be desirable. This is another debate, but part of what the French electorate gave voice to on the May $29^{\text {th }}$ is the demand for another Europe, capable of protecting and guaranteeing the French social protection model.

\section{Figure 1}

\section{Nay Average Probability by Number of Nationalistic Threats and Ideology}

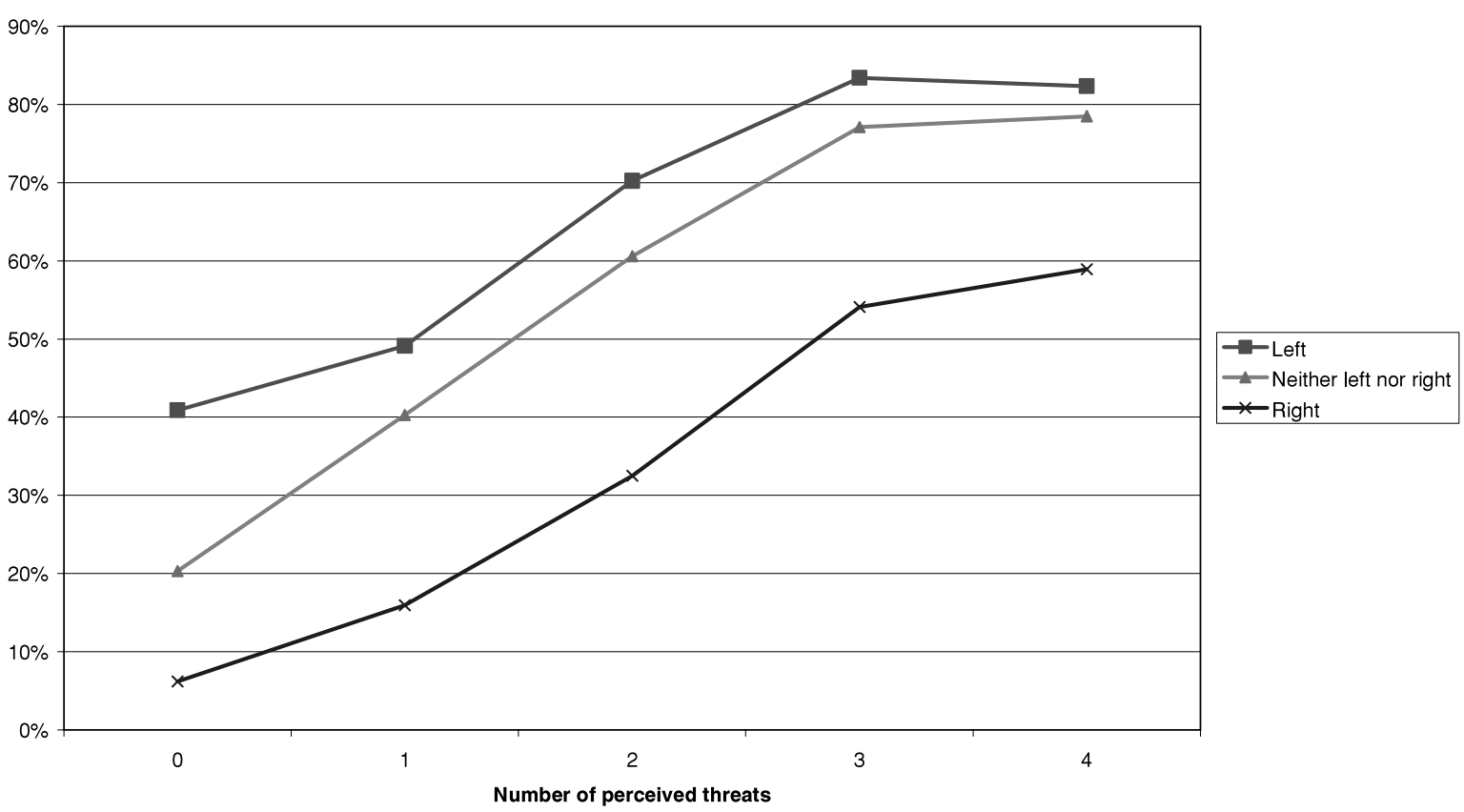




\section{Notes}

* Our warmest thanks to our colleagues, Chantal Barry, Arianne Chebel d'Appolonia, and Manlio Cinnalli for their remarks on and their help with this piece.

1. Opinion polls foresaw a negative response on the part of the electorate for the first time in early March and the "no" vote gathered the majority of the respondents throughout the March-May period except for a couple of surveys at the end of April.

2. This debate on interpreting the referendum also proceeds from the specificities of this particular election, both for the voters and the parties (see Kobach 1993; Butler and Ranney 1994; Grossman 1995; Budge 1996).

3. In some way the open/closed cleavage is related to the materialist/ post-materialist tradition of research (Inglehart 1977; 1990), but this theory stresses that voters are simultaneously aligned both on the left/right axis (which more or less matches social and economic materialist issues) and on the open/closed cleavage (which matches cultural post-materialist issues).

4. The data come from two pre-electoral surveys conducted by Sylvain Brouard under the "European issues and referendum" project. The two pieces of fieldwork were conducted by TNS-Sofrès for the first wave between the $13^{\text {th }}$ and the $21^{\text {st }}$ of April $(\mathrm{n}=1006)$ and for the second between the $11^{\text {th }}$ and the $17^{\text {th }}$ of May $2005(n=1009)$. The Ministry of the Interior and the Governmental Information Service (SIG) provided a substantial part of the funding. Results consist mostly of a secondary analysis of a combined dataset of both waves of this survey Using pre-electoral surveys for this kind of analysis is often troublesome, but our data are confirmed by post-electoral polls conducted by the major polling firms in France. For more details, please contact the authors directly.

5. In spite of the enduring debate on which counts the most in French politics: the left/right cleavage or the partisan link? (see Converse and
Pierce 1986, 93; Percheron 1977; Fleury and Lewis-Beck 1993; and LewisBeck, Belanger, Chiche, and Tiberj 2005).

6. Whether the Prime Minister Jean-Pierre Raffarin should campaign was publicly addressed even by political figures within his own party, the UMP. For some, he was so unpopular at that time that he would crystallize all the resentments against him and his unpopularity would translate into a negative vote for the referendum. However, it was quite hard to disentangle the unpopularity of the prime minister from the unpopularity of the president, as they were highly correlated. Whatever the variable chosen, it would be a very good proxy for the other.

7. If we take only the raw frequencies of responses, the Greens would rank third in importance (with 13.5\% of respondents, $21.5 \%$ for the UMP, and $32.5 \%$ for the Socialist Party), although an electoral success for them consists of gaining more than $5 \%$ of the popular vote.

8. This relatively low level of satisfaction with the government within this particular sector of the electorate is explained by the high proportion of UDF sympathizers among them, simultaneously critics and strongly pro-European.

9. In an experiment we carried out on attitudes toward particular groups of immigrants, $41 \%$ of interviewees perceived East Europeans as a direct threat for people like them, whereas only $35 \%$ responded the same for Maghrebian immigrants (see Brouard and Tiberj 2005).

10. When asked how likely they were to vote socialist, $77 \%$ of the yeas thought it probable and $18 \%$ thought it possible, whereas $64 \%$ of the nays thought it probable and $22 \%$ possible.

11. $45 \%$ of French citizens with a positive attitude toward Europe judge French EU-membership positively, 37\% would regret if the project were abandoned, and $33 \%$ would feel relieved.

\section{References}

Bélanger, Eric, Michael Lewis-Beck, Jean Chiche, and Vincent Tiberj. 2005. "Party, Ideology and the French Voter: Dynamics from the 2002 Electoral Panel." Unpublished manuscript.

Bélot, Céline, and Bruno Cautrès. 2004. "l'Europe, invisible mais omnipésente." In Le nouveau désordre électoral, eds. Bruno Cautrès and Nonna Mayer. Paris: Presses de Sciences Po, 119-145.

Bréchon, Pierre. 2004. "Crise de confiance dans les élites politiques." In $L e$ nouveau désordre électoral, eds. Bruno Cautrès and Nonna Mayer. Paris: Presses de Sciences Po, 47-70.

Brouard, Sylvain, and Vincent Tiberj. 2005. Français comme les autres? Une enquête auprès des citoyens d'origine maghrébine, africaine et turque. Paris: Presses de Sciences Po.

Budge, Ian. 1996. The New Challenge of Direct Democracy. Oxford: Blackwell Publishers.

Butler, David, and Austin Ranney eds. 1994. Referendums around the World: The Growing Use of Direct Democracy. London: Macmillan.

Cautrès, Bruno, and Vincent Tiberj. 2005. Une sanction du gouvernement mais pas de l'Europe: Les élections européennes de juin 2004. Paris : Cahiers du CEVIPOF n 41.

Chiche, Jean, Brigitte Le Roux, Pascal Perrineau and Henry Rouanet. 2000. "L'espace politique des électeurs français à la fin des années 1990." Revue française de science politique 50 (3) : 463-487.

Converse, Philip, and Roy Pierce. 1993. "Comment on Fleury and LewisBeck: 'Anchoring the French Voter: Ideology versus Party." "Journal of Politics 55 (4): 1110-1117.

1986. Political Representation in France. Cambridge: Harvard University Press.

Evans, Jocelyn, and Nonna Mayer. 2005. "Electorates, New Cleavages and Social Structures." In Developments in French Politics 3, eds. Allistair Cole, Patrick Le Galès, and Jonah Levy. Houndmills: Palgrave Macmillan, 35-54.

Fleury, Christopher, and Michael Lewis-Beck. "Anchoring the French Voter: Ideology versus Party." Journal of Politics 55 (4): 1100-1109.

Franklin, Mark, Michael Marsh, and Lauren McLaren. "Uncorking the Bottle: Popular Opposition to European Unification in the Wake of Maastricht." Journal of Common Market Studies 32 (4): 455-472.

Franklin, Mark, Cees Van der Eijk, and Michael Marsh. "Referendums' Outcome and Trust in Government: Public Support for Europe in the Wake of Maastricht." West European Politics 18: 101-117.

Grossman, L. 1995. The Electronic Republic. New York: Viking.
Inglehart, Ronald. 1977. The Silent Revolution: Changing Values and Political Styles among Western Publics. Princeton: Princeton University Press. . 1990. Culture Shift in Advanced Industrial Society. Princeton: Princeton University Press.

Kobach, K. 1993. The Referendum. Aldershot: Dartmouth.

Laurent, Annie, and Nicholas, Sauger. 2005. Le référendum de ratification du traité constitutionnel européen : comprendre le "Non » français. Paris: Cahiers du CEVIPOF n ${ }^{\circ} 42$.

Mayer, Nonna. 1999. Ces Français qui votent FN. Paris: Flammarion.

Mayer, Nonna, and Vincent Tiberj. "Issues 2002: Law and Order?" In The French Voter: Before and After the 2002 Election, ed. Michael LewisBeck. Houndmills: Palgrave Macmillan, 33-46.

Mergier, Alain et al. 2005. Le jour où la France a dit non? Comprendre le référendum du 29 mai 2005. Paris: Fondation Jean-Jaurès-Plon.

Morel, Laurence. 2005. "Les usages du référendum sous la Cinquième République: un Président en perte d'initiative." In Le référendum de ratification du Traité constitutionnel européen: comprendre le non français, eds. Annie Laurent and Nicolas Sauger. Paris: Cahier du CEVIPOF n 42, 7-25.

. 1996. "France: Towards a Less Controversial Use of the Referendum?" In The Referendum Experience in Europe, eds. M. Gallagher and P. Uleri. Basington and London: Macmillan.

Perrineau, Pascal. 2005. "Le referendum françois du 20 mai 2005." In Le Vote Européen: 2004-2005, ed. Pascal Perrineau. Paris: Presses de Sciences Po, 238-240.

Percheron, Annick. 1977. "Ideological Proximity among French Children: Problems of Definition and Measurement." European Journal of Political Research 5: 53-81.

Piar, Christophe, and Jacques Gerstlé. 2005. "Le cadrage du référendum sur la Constitution européenne." In Le référendum de ratification du Traité constitutionnel européen: comprendre le non français, eds. Annie Laurent and Nicolas Sauger. Paris: Cahier du CEVIPOF n ${ }^{\circ} 42,42-73$.

Sauger, Nicolas, Sylvain Brouard, and Emiliano Grossman. 2006. Les Français contre l'Europe? Les sens du référendum du 29 mai 2005. Paris: Presses de Sciences-Po.

Schweisguth, Etienne. 2002. "La dépolitisation en questions." In La démocratie à l'épreuve: une nouvelle approche de l'opinion des Français, eds. Gérard Grunberg, Nonna Mayer, and Paul Sniderman. Paris: Presse de Sciences Po, 51-86.

Van der Eijk, Cees, and Mark Franklin, eds. 1996. Choosing Europe? The European Electorate and National Politics in the Face of Union. Ann Arbor: University of Michigan Press. 